\title{
HAEMATOLOGY AND GONAD HISTOLOGY OF OREOCHROMIS NILOTICUS (LINNAEUS, 1758) FED CARICA PAPAYA SEED MEAL
}

\author{
SOLOMON, S.G.; UGONNA, B.O.; OLUFEAGBA, S.O. \& OKOMODA, V. T.* \\ Department of Fisheries and Aquaculture, University of Agriculture, Makurdi, Nigeria. \\ *Corresponding author: okomodavictor@yahoo.com
}

\begin{abstract}
Solomon, S.G.; Ugonna, B.O.; Olufeagba, S.O. \& Okomoda, V. T., (2017). Haematology and gonad histology of Oreochromis niloticus (Linnaeus, 1758) fed Carica papaya seed meal. Braz. J. Aquat. Sci. Technol. 21(1). elSSN 1983-9057. DOI: 10.14210/bjast.v21n1. This research investigated the effect of Pawpaw (Carica papaya) seed meal (PSM) on haematological parameters and gonad histology of Oreochromis niloticus (Linnaeus, 1758). Freshly hatched fry of $O$. niloticus were fed blended commercial diet (35\%CP) mixed with varying levels of PSM $\left(0,2,4,6\right.$ and $\left.8 \mathrm{gkg}^{-1}\right)$ for $28 \mathrm{days}$ in fifteen aquarium tanks $\left(30 \times 30 \times 20 \mathrm{~cm}^{3}\right)$. Resultant fingerlings were maintained in outdoor concrete tanks $\left(1 \times 1 \times 1 \mathrm{~m}^{3}\right)$ for 140 days till they gained an average weight of $30 \mathrm{~g}$. Haematological analysis and gonad histology was done to determent the effect of the PSM on the fish. Haematological changes observed in this study did not revealed detrimental effect of feeding of PSM. However, histological evaluation of the gonads showed various degrees of deformities and tends to increase in severity as the levels of PMS increased. It was concluded that PSM might not affect the health status of the Nile tilapia but lead to sterility of the fish.
\end{abstract}

Key Words: Nile Tilapia, Pawpaw, Degenerated gonads, Sterility.

\section{INTRODUCTION}

The culture of tilapia is exemplary among many freshwater fishes due to several factors (FAO, 2002). This includes hardness, high resistance to diseases, tolerance to wide range of salinity, high yield potential and acceptability of natural and artificial feed (Meyer 2002, El-Sayed, 2006, Olufeagba and Okomoda 2015). However, due to the precocious maturation and uncontrolled spawning notice among this group of fish (Ekanem and Okoronkwo, 2003), several methods have been developed to control reproduction for cost effective production (Toguyeni et al., 2002; Olufeagba and Okomoda 2015). Of all the methods of reproduction control, sex reversal is the most used and effective technique (Pandian and Varadaraj, 2005). This technique presents an opportunity to overcome the limitation of precocious breeding by converting genotypic females into phenotypic males or vice versa using appropriate hormone (Nakamura and Takahashi, 1973; Toguyeni, et al., 2002; Davis et al., 2010 Babiak et al., 2012). However, the use of steroid hormone in food fish have raised a lot of question about possible health implication (Ayotunde and Ofem, 2008; Jegede, 2010). Hence, suitable natural alternatives that are biodegradable are currently the focus of many researches.

Pawpaw (Carica papaya) seed meal (PSM) is one of such alternative with phytochemical that have found a place of purpose in all male production of tilapia. Its active ingredient, masculation potential and the effect on the growth of fed fish have been well reported (Udoh and Kehinde, 1999; Ekanem and Okoronkwo,
2003; Ayotunde and Ofem, 2008; Kobayashi et al., 2008; Omeje 2016). However, there is paucity of information about the health status of fish fed varying levels of inclusion of this natural sex reversing agent. Biochemical and physiological biomarkers as well as some histological examinations are frequently used for detecting or diagnosing the effects of different substances to fish (De La Fuente et al., 1999) and can also be used to evaluate the fish's health conditions (Solomon and Okomoda 2012). Shah and Altindag (2004) noted that studies on fish blood particular gives the possibility of knowing the physiological conditions within the fish long before there is an outward manifestation of any detrimental condition and effect. This is because some parameters of the blood changes in response to reflect the imbalance and stressful condition in which the fish is subjected (Solomon and Okomoda 2012). However, this outward manifestation of effect could irreversible in nature significantly affecting functions such as behaviour, growth, reproduction, meat quality and survival (EINaga et al., 2005). Due to the perceived prospect of PSM for all male tilapia production, this study was designed to evaluate the haematological and gonad histological effects of PSM feeding on Nile tilapia.

\section{MATERIAL AND METHOD}

Fresh pawpaw seeds were obtained from ripe fruits bought from the Wadata market in Makurdi and transported to the Department of Fisheries and 
Aquaculture research farm, University of Agriculture Makurdi, Nigeria. The seeds were dried under shade and milled into a fine powder; kept in a dry, clean, airtight plastic container at room temperature until usage. Coppen feed (35\% crude protein) purchased from a reputable feed store in North Bank, Makurdi Nigeria were blended, sieved (with $0.5 \mathrm{~mm}$ sieve) and mixed with the prepared PSM at the of $0,2,4,6$ and $8 \mathrm{~g} / \mathrm{kg}$ of feed (respectively for the five treatments of the study). Freshly hatched fry of $O$. niloticus were then fed in triplicate (50 fry per aquarium of $30 \times 30 \times 20 \mathrm{~cm}^{3}$ ) for a treatment period of 28days. After this, the resultant fingerlings were transferred to triplicate concrete tanks $\left(1 \times 1 \times 1 \mathrm{~m}^{3}\right)$ according to the previous treatment applied and maintained for a recovery period of five months. The fish were fed at $5 \%$ body weight twice per day with Coppens (without the inclusion of PSM). Water quality was kept optimum during the treatment and recovery period, by regular water change with continuous aeration $\left(\mathrm{T}^{\circ} \mathrm{C}=26.5 \pm 0.7 ; \mathrm{pH}=7.00 \pm 0.26\right.$; Cond. $=570 \pm 2.90 ;$ TDS 245.0 $\pm 0.80 ; \mathrm{DO}=4.59 \pm 0.50$ ). This was monitored daily using a VSI professional plus multi-parameter water quality meter (Model 13M10065, Made in the USA).

At the end of the study, all the surviving fish from each treatment were tranquilized with $150 \mathrm{mg} / 1$ solutions of tricaine methane sulphonate (MS222) (Wagner et al., 1997). Pooled blood was collected from ten fish per treatment by cutting the caudal peduncle. The collected blood was placed in coded $1.5 \mathrm{~mL}$ heparinized plastic tubes, stored on ice according to the procedures established by Campbell and Murru (1990). Haematocrit (Hct;\%) or Packed cell volume (PCV) in the blood samples was assayed by microcentrifugation at $3500 \times \mathrm{g}$ for $10 \mathrm{~min}$ of standard heparinized microhaematocrit capillary tubes and measuring the percentage of packed cell volume (Barros et al., 2002). Haemoglobin concentration ( $\mathrm{Hb} ; \mathrm{g} \mathrm{dL}-1)$ was spectrophotometrically measured on the basis of cyanmethemoglobin procedure by Drabkin (1945). The number of red (RBC) and white blood cell (WBC) were counted microscopically in a haemocytometer, using an improved Neubauer chamber after diluting blood samples with Hayem solution (for RBC) or Turk solution (for WBC) (Barros et al., 2002). Mean corpuscular volume $(\mathrm{MCV} ; \mathrm{fl})$, mean corpuscular haemoglobin ( $\mathrm{MCHb} ; \mathrm{pg})$ and mean corpuscular haemoglobin concentration (MCHC;\%) were calculated for each sample according to the method of Klinger et al. (1996) as shown below;

$$
M C V=\frac{P C V \times 1000}{R B C \times 10^{12}}
$$

where PCV $=$ Packed Cell Volume $\mathrm{RBC}=$ Red Blood Cell Count

$$
M C H=\frac{H b\left(g \cdot L^{-1}\right)}{R B C \times 10^{12} \cdot L^{-1}}
$$

where $\mathrm{Hb}=$ haemoglobin concentration

$\mathrm{RBC}=$ Red Blood Cell Count

$$
M C H C=\frac{H b\left(g \cdot L^{-1}\right)}{P C V\left(L \cdot L^{-1}\right)}
$$

All the tranquilized fish were however dissected to observe the phenotypic character of the gonads. The male, female and infertile character were given in the presence of clearly observable testis, egg sac or immature gonad (characterized by thread-like appearance or irregular shapes) respectively. Histological examination of gonads was done to determine the effect of PSM on the reproductive organs. Specimens of the gonads from each treatment were fixed for $24 \mathrm{~h}$ in formalin-saline solution (1:1 of $10 \%$ formalin and $0.9 \%$ sodium chloride). Histological sections of $5 \mu$ thickness was then prepared following standard procedures described by Luna, (1992). Descriptive statistics of the haematological parameters were analysed using mini tab 14 computer software followed by one-way analysis of Variance (ANOVA). When significant $(P<0.05)$ differences were observed, data were separated using Fisher's least significant difference.

\section{RESULTS}

The result of the haematology parameters of $O$. niloticus treated with pawpaw seed meal is given in Table 1. White Blood count (WBC), Red Blood count (RBC) and Platlet (PLT), were similar in fish previously fed the experimental diet and those fed the control diet $(P>0.05)$. However, Packed cell volume (PCV), Haemoglobin $(\mathrm{Hb})$ Mean corpuscular haemoglobin $(\mathrm{MCH})$ and Mean corpuscular volume (MCV) were higher $(P<0.05)$ in fish previously fed $4 \mathrm{gkg}^{-1} \mathrm{PSM}(23.0$, $7.75,23.14$ and 68.66 respectively) and least in those fed the control diet $(21.0,7.25,21.02$ and 60.88 respectively). The reverse trend was however, observed in the in Mean corpuscular haemoglobin count (MCHC).

The effectiveness of pawpaw seed as a natural hormone in the production of all male $\mathrm{O}$. niloticus is demonstrated in Figure 1. Result obtained revealed significant difference, increase in percentage male up to inclusion of $6 \mathrm{gkg}^{-1}$ and subsequently reduced. Female tilapia was noticed in $2 \mathrm{gkg}^{-1}$ and the control treatment but not in the other treatment. However, sterile and infertile percentages increased significantly 
in O. niloticus fed $4 \mathrm{gkg}^{-1}$ and beyond. Histological examinations of the gonads of treated and control groups of $O$. niloticus is given in Plates 1-7. Result revealed significant visible effect of PSM feeding on the gonad structure. While normal stages of oocyte development were observed in females of the control groups, degenerative stromas were observed in the group fed the least treatment $\left(2 \mathrm{gkg}^{-1}\right)$. Ovary histology of the other groups was impossible due to absence of female specimen. However, the testis histology of the control group and that of those previously fed $2 \mathrm{gkg}^{-1} \mathrm{PSM}$ shows evidence of normality with presences of primary and secondary spermatocyte with well-defined connective tissues. However, beyond $2 \mathrm{gkg}^{-1}$ pawpaw feeding level, significant abnormalities were observable in the gonad. Gonad of fish previously fed $4 \mathrm{gkg}^{-1}$ showed evidence of deformation in the seminiferous tubules, while degeneration was evident in the spermatozoa present in the ductus deference of the fish group fed $6 \mathrm{gkg}^{-1}$. More so, deformation of seminiferous lobule and severe erosion of the spermatozoa were visibly seen in fish group fed $8 \mathrm{gkg}^{-1}$.

Table 1 - Haematological parameters of Oreochromis niloticus after a four month recovery period from pawpaw seed treatment at varying levels of inclusions.

\begin{tabular}{lccccc}
\hline Parameters & TRT 1 & TRT 2 & TRT 3 & TRT 4 & TRT 5 $^{\text {PCV }}$ \\
\hline PCV & $21.00 \pm 0.00^{\mathrm{d}}$ & $21.5 \pm 0.01^{\mathrm{c}}$ & $23.00 \pm 0.02^{\mathrm{a}}$ & $22.55 \pm 21.55^{\mathrm{b}}$ & $21.55 \pm 0.05^{\mathrm{c}}$ \\
$\mathrm{Hb}$ & $7.25 \pm 0.05^{\mathrm{c}}$ & $7.35 \pm 0.05^{\mathrm{bc}}$ & $7.75 \pm 0.05^{\mathrm{a}}$ & $7.45 \pm 0.05^{\mathrm{b}}$ & $7.40 \pm 0.00^{\mathrm{bc}}$ \\
WBC & $2.25 \pm 0.05$ & $2.28 \pm 0.03$ & $2.30 \pm 0.00$ & $2.38 \pm 0.13$ & $2.28 \pm 0.03$ \\
RBC & $3.45 \pm 0.05$ & $3.40 \pm 0.00$ & $3.35 \pm 0.02$ & $3.40 \pm 0.04$ & $3.36 \pm 0.01$ \\
PLT & $18.25 \pm 0.25$ & $18.00 \pm 0.01$ & $18.20 \pm 0.00$ & $18.25 \pm 0.05$ & $18.00 \pm 0.00$ \\
MCH & $21.02 \pm 0.45^{\mathrm{c}}$ & $21.62 \pm 0.15^{\mathrm{bc}}$ & $23.14 \pm 0.15^{\mathrm{a}}$ & $21.91 \pm 0.15^{\mathrm{b}}$ & $22.06 \pm 0.04^{\mathrm{b}}$ \\
MCV & $60.88 \pm 0.88^{\mathrm{d}}$ & $63.24 \pm 0.01^{\mathrm{c}}$ & $68.66 \pm 0.00^{\mathrm{a}}$ & $66.33 \pm 0.15^{\mathrm{b}}$ & $64.24 \pm 0.06^{\mathrm{c}}$ \\
MCHC & $34.53 \pm 0.24^{\mathrm{a}}$ & $34.19 \pm 0.24^{\mathrm{ab}}$ & $33.69 \pm 0.22^{\mathrm{bc}}$ & $33.04 \pm 0.30^{\mathrm{c}}$ & $34.34 \pm 0.08^{\mathrm{ab}}$ \\
\hline
\end{tabular}

Mean in the same row with different superscripts differ significantly $(\mathrm{P}<0.05)$

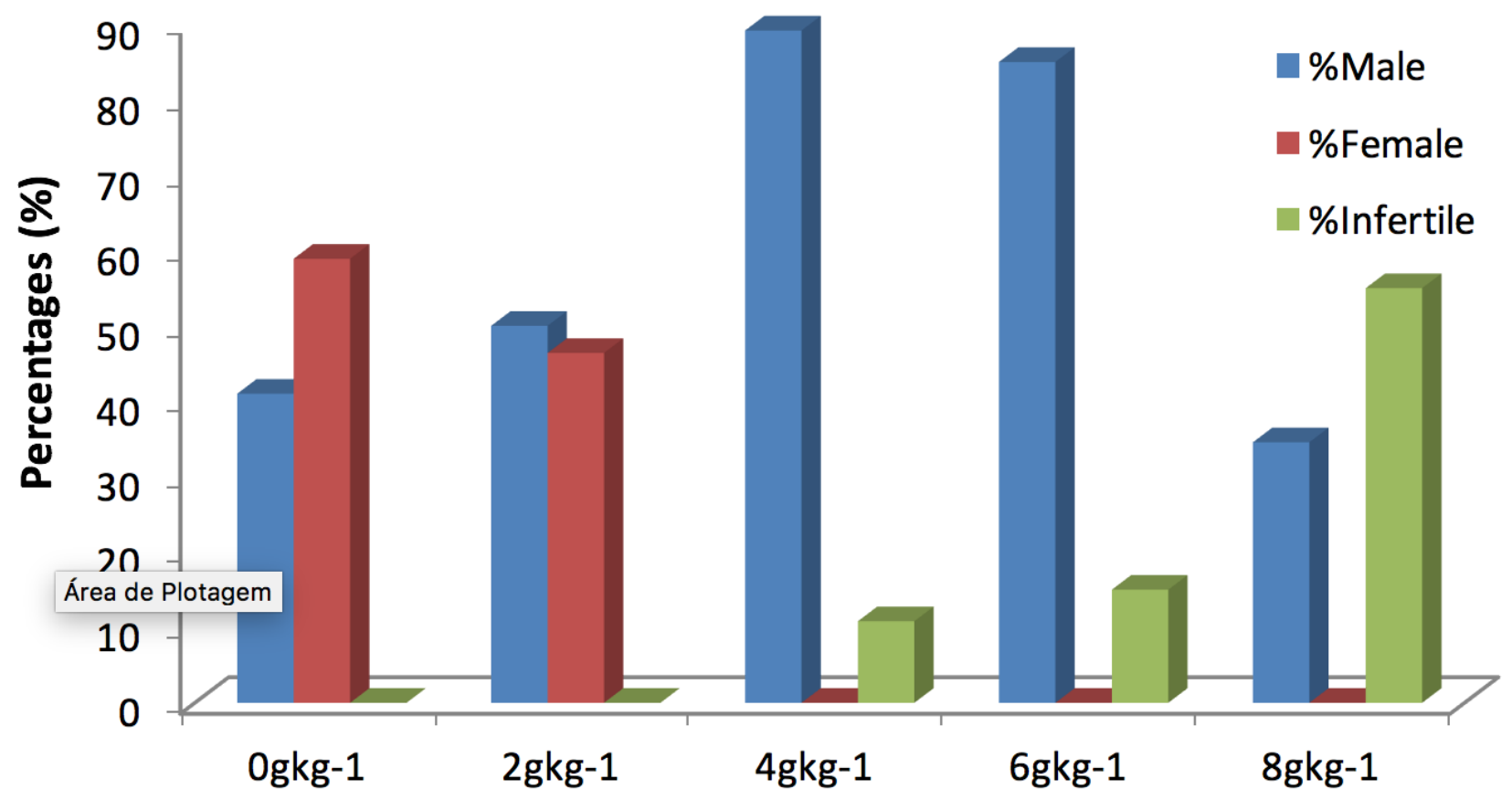

Figure 1 - Sexual phenotype of $O$. niloticus after four month recovery from pawpaw seed treatment at varying levels of inclusion. 


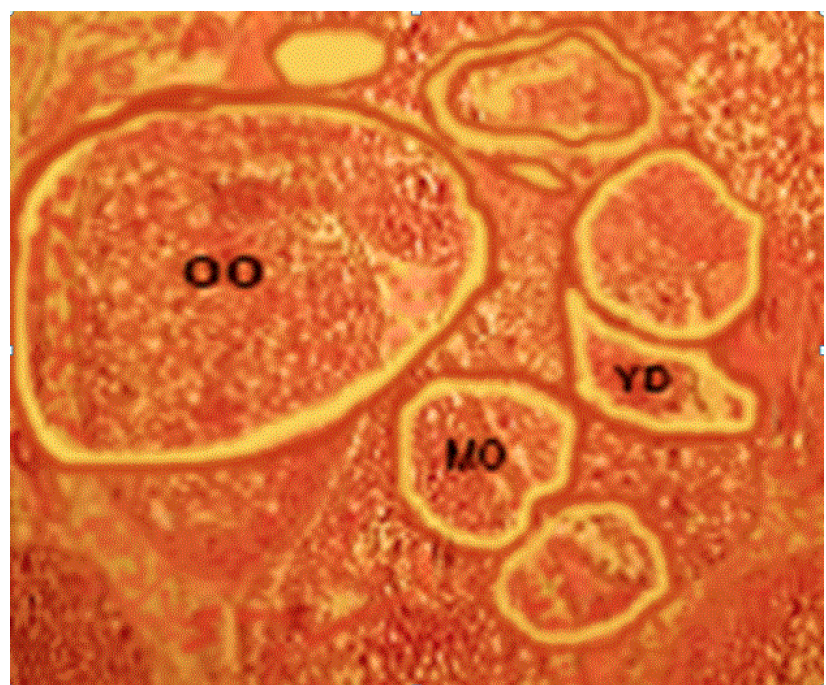

Plate 1 - Photomicrograph of O niloticus ovary fed 0g/kg PSM showing normal stages of oocytes development (OO), yolk droplet (YD) and matured oocytes (MO).

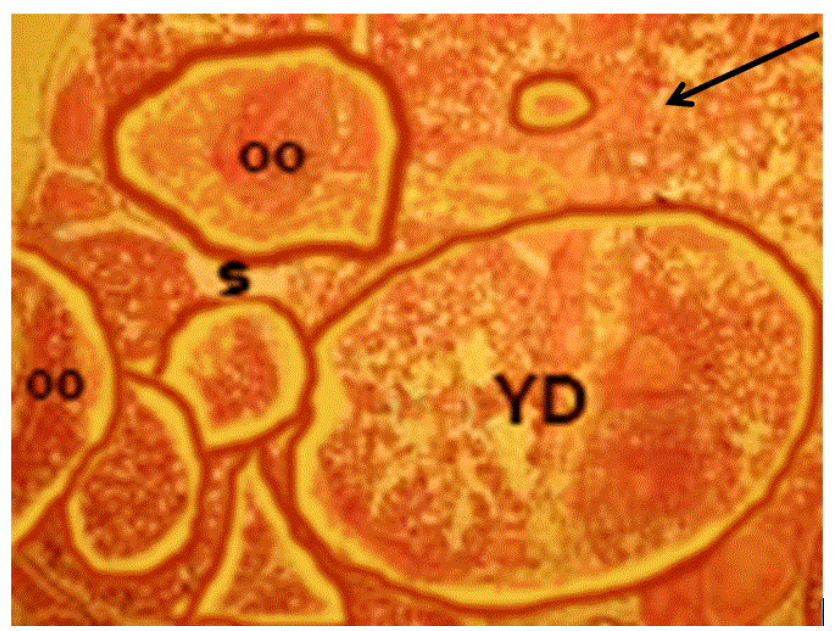

Plate 2 - Photomicrograph of O. niloticus Ovary $2 \mathrm{~g} / \mathrm{kg}$ of feed showing matured yolk droplet (YD), Developing follicle (arrow), Degenerated Stroma (S) and Oocyte (oo).

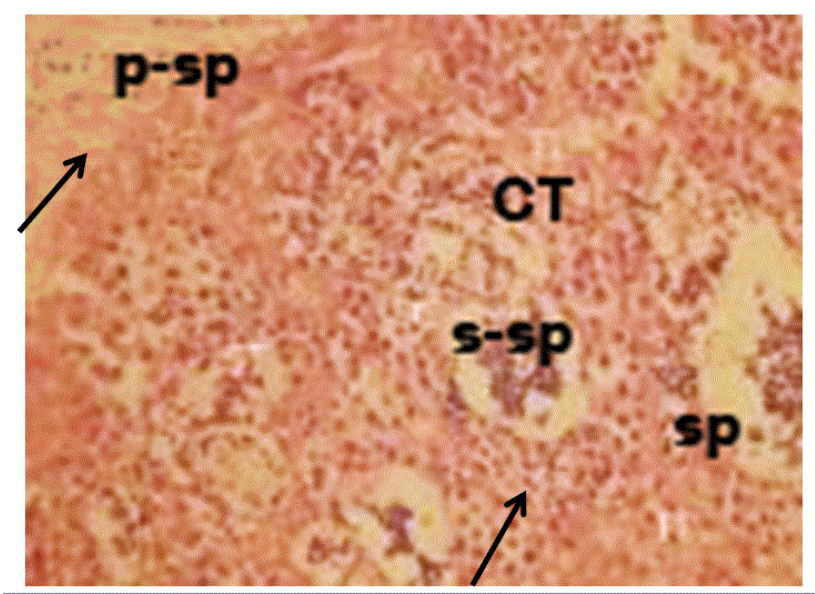

Plate 3 - Photomicrograph of O. niloticus testis fed $0 \mathrm{~g} / \mathrm{kg}$ feed (control) showing primary spermatocytes (P-SP), connective tissue (CT), Secondary spermatocyte and normal spermatozoa.

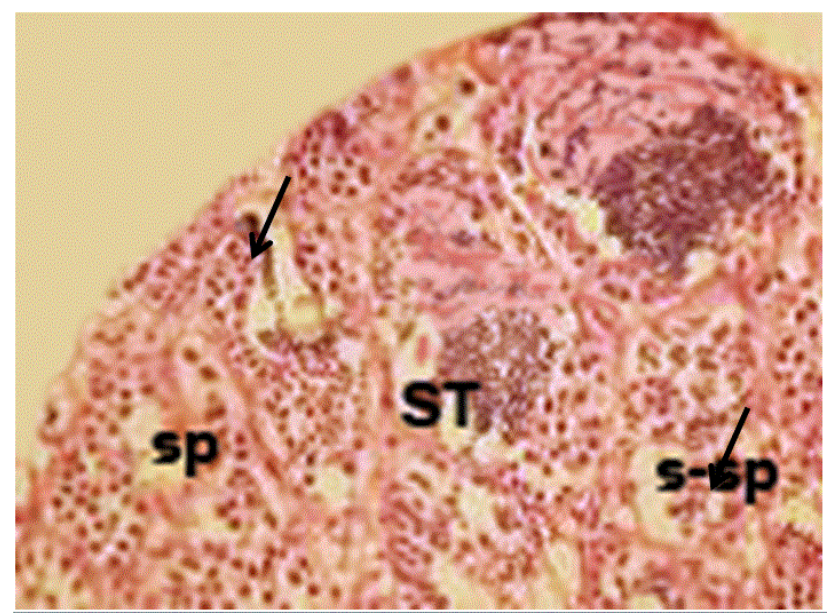

Plate.4 - Photomicrograph of O. niloticus testis feed $2 \mathrm{~g} / \mathrm{kg}$ feed showing connective tissue (CT), spermatocytes, scanty spermatozoa and spermatid (ST).

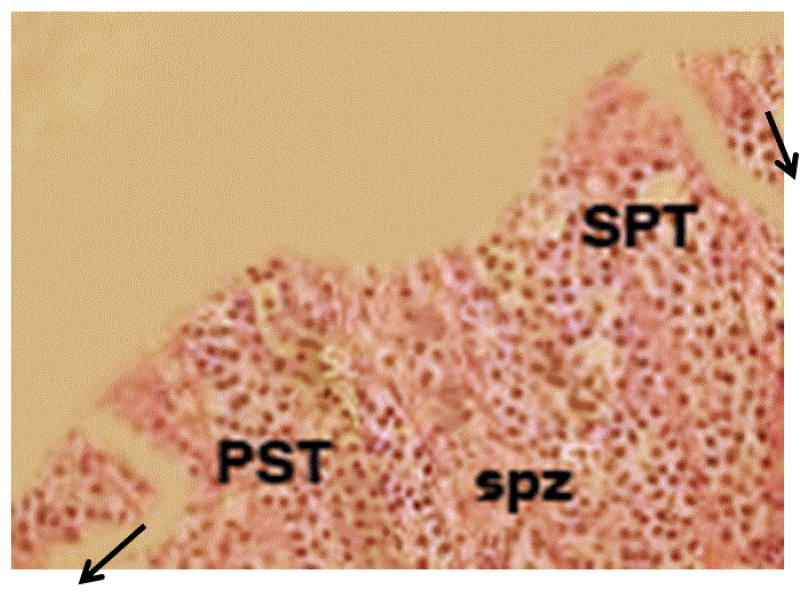

Plate 5 - Photomicrograph of $O$. niloticus testis feed $4 \mathrm{~g} / \mathrm{kg}$ feed showing connective tissue, Secondary spermatocyte (SPT), deformation in seminiferous tubules and spermatozoa (SPZ).

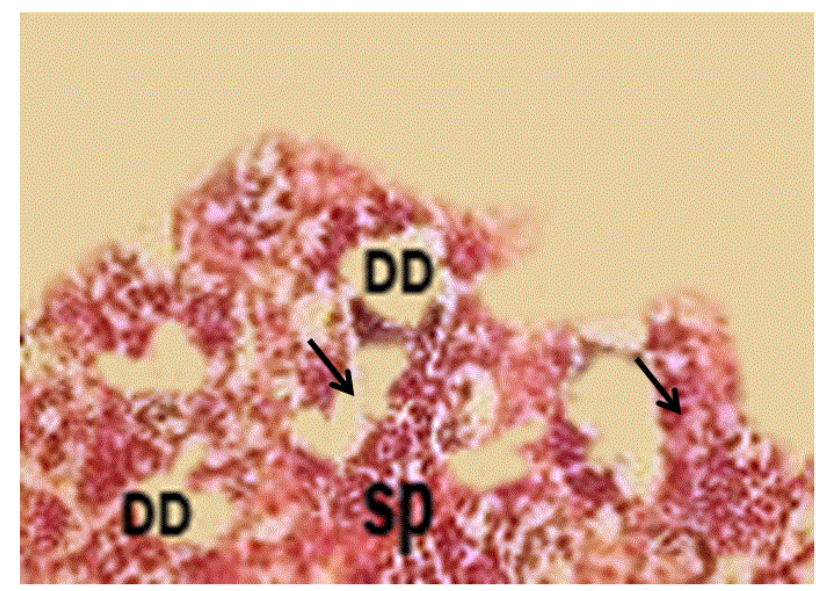

Plate 6 - Photomicrograph of 0 . niloticus testis feed $6 \mathrm{~g} / \mathrm{kg}$ feed showing spermatid (ST), Secondary spermatocyte and degeneration of spermatozoa in ductus deference (DD). 


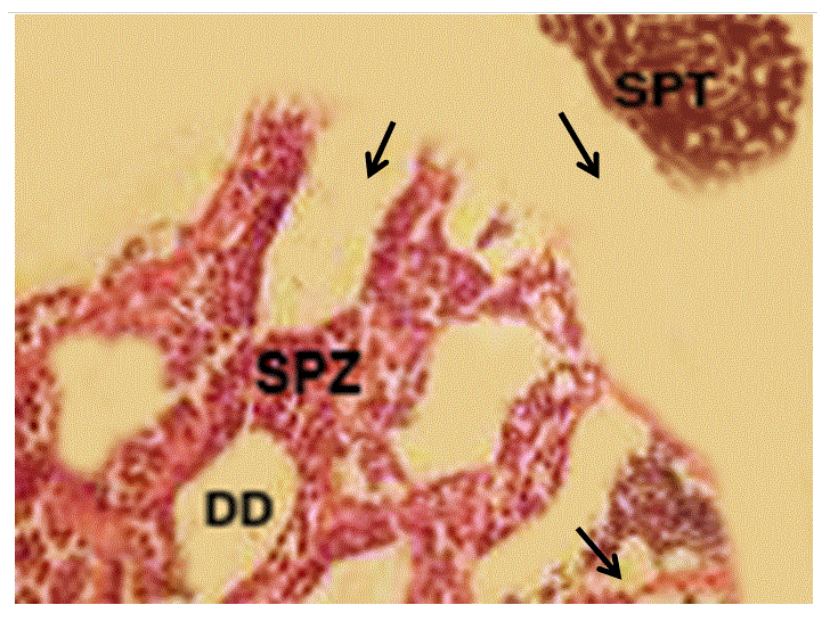

Plate 7 - Photomicrograph of 0 . niloticus testis feed $8 \mathrm{~g} / \mathrm{kg}$ feed showing spermatocytes, deformation in seminiferous lobule and severe erosion of spermatozoa (SPZ).

\section{DISCUSSION}

The outcome of this study revealed reduction in the levels of $\mathrm{PCV}, \mathrm{Hb}, \mathrm{MCH}$ and $\mathrm{MCV}$ beyond $4 \mathrm{gkg}^{-1}$ PSM treatment while RBC, PLT and WBC were statistically same. Omeje (2016) had earlier reported insignificant reduction in RBC of treated groups despite feeding as much as $30 \mathrm{gkg}^{-1} \mathrm{PSM}$ in the diet of Oreochromis mossambicus. However, Ayotunde et al. (2010) reported significant decrease in RBC counts of Clarias gariepinus fingerlings exposed to various levels of pawpaw seed extract ranging from 100 to $500 \mathrm{mg} / 20 \mathrm{~L}$. Also Kavitha et al. (2012) reported a decreased value for RBC in Common carp Cyprinus carpio treated with $12.40 \mathrm{mg} / \mathrm{L}$ of Moringa oleifera seed extract. Red blood cells (erythrocytes) contain haemoglobin and its main function is to transport oxygen and carbon dioxide. Hence, any significant reduction or changes in its number may be indicative of anemia or stress (De Pedro et al., 2005). It is the most abundant cell type and has proved to be a highly variable blood parameter among different fish species (Daneshvar et al., 2012) and among the same species as dictated by different environmental conditions and feed types (Solomon and Okomoda 2012). Hence, the observation of this study is suggestive that feeding of PSM may not have affected the health status of the fish significantly. However, the finding of Ayotunde \& Ofem, (2008) who reported significant decrease in haemoglobin of $O$. niloticus at a concentration of $5.0 \mathrm{mg}$ of pawpaw seed extract per litre of culture water further suggest that dosage and mode of administration of PSM could lead to differentiation in the outcome of studies of different experiments. This result also agrees with the findings of Ozovehe (2012) who reported no significant influence of Moringa oleifera on the WBC of Clarias gariepinus. Ayotunde et al. (2010), however, reported significant decreased in the levels of WBC of O. niloticus fed PSM. While, Omeje (2016) had results which indicated insignificant effect of PSM on the WBC count in $O$. mossambicus. Decreased in WBC means reduction in the disease fighting capacity of the fish (Rapatsa \& Moyo 2013). While, Vázquez \& Guerrero, (2007) had stated that thrombocytes (platelets) plays key role in blood clotting, Omeje (2016) concluded that, xenobiotic treatments that result in the increase of these blood parameters are associated with an improved immune system functioning, compared to treatments that result in their decrease, which are associated with a compromised immune. In this study, there was no significant difference in the means of these parameters between the treatment groups and the control. Hence, justifying the assumption that treating O. niloticus with PSM as a natural sex reversal agent will not compromise the health status of the fish.

Gender has been previously implicated as one of the most important factors influencing the haematological parameters of different fish species (Santos et al., 2009). Omeje (2016) had earlier reported that RBC count of male $O$. mossambicus was significantly higher than that of the females. Similarly, the findings of Karimi et al. (2013) also revealed the presence of more RBC in male yellow fin sea bream (Acanthopagrus latus) compared to the females. However, the findings of Santos et al. (2009) suggest insignificant difference in the haematological parameters of male and female fat snook (Centropomus parallelus). According to Acharya \& Mohanty (2014), the significantly higher values of $\mathrm{RBC}$, haematocrit and haemoglobin observed often and predominantly in male of many fish species could be linked to higher metabolic rate. This is because these parameters are linked to dissolved oxygen carrying capacity of the blood which is important for all activities. The increase value of these parameters in the present study (although not significant in some parameters) could therefore be linked to the sex ratio screwed toward male. Hence, these parameters peaked in the group fed $4 \mathrm{gkg}^{-1}$ due to higher percentage of male and no female population. It thereafter reduced due to reduction in male percentages and increase in sterile fish.

Many researches in aquaculture have examined the effect of phytoestrogenous extracts in various plants on the growth, digestive and immune-stimulation systems of many animals (Francis et al., 2001; 2002; 2005; Stadtlander et al., 2008; Jegede, 2011; Abdelhak et al., 2013; Ampofo-Yeboah, 2013 Angeles and Chien 2015). Only few studies considered the effect of phytoestrogens on histology of fed fish. The result obtained showed various levels of deformities in both male and 
female gonads of the various groups fed the pawpaw seeds. Ovary histology of the groups treated beyond $2 \mathrm{gkg}^{-1} \mathrm{PSM}$ could not be obtained due to the absence of female. This suggest that PSM is efficient in sexreversing $O$. niloticus. More so, degenerative stromas were female observed in the group of fish treated with $2 \mathrm{gkg}^{-1}$ PSM. Jegede and Fagbenro, (2008) had earlier reported necrotic ovaries in Tilapia zilli when fed basal diet containing Neem leaves, (Azadirachta indica) incorporated at $2.0 \mathrm{gkg}^{-1}$. Similar gonadal histological changes were reported by Jegede, (2010) and Jegede, (2011) when Hibiscus rosa-sinesis leaves (at $3.0 \mathrm{gkg}^{-1}$ ) and Aloe vera latex $\left(2.0 \mathrm{mlkg}^{-1}\right)$ were incorporated in the diet of Nile tilapia respectively. Endocrine disrupting compounds (EDCs) in plant such as phytoestrogens have been implicated as having the ability to impair animal reproduction either by affecting gonad differentiation or by delaying maturation (Omeje 2016). This is evident in the level of degeneration observed in the group fed $2 \mathrm{gkg}^{-1}$ and absence of females in groups treated beyond $2 \mathrm{gkg}^{-1}$ hence screwing sex ratio in favour of male. However, just as reported earlier, beyond $4 \mathrm{gkg}^{-1}$, the male percentages begin to reduce and screw in favour of sterility. To further understand the biology of fish fed higher PSM levels, histological examination of the testis revealed deformation in the seminiferous tubules, degeneration in the spermatozoa and seminiferous lobule as well as severe erosion of the spermatozoa. The degree of deformities observed tends to intensify as the levels of inclusion of the PSM increased. Similar findings were noted when PSM were included in the basal diet of Nile tilapia at $120 \mathrm{~g} \mathrm{~kg}^{-1}$ diets as (Abdelhak et al., 2013). The authors further opined that the significant gonadal histological changes evident in high doses were irreversible while medium as well as low dosage may have reversible effects. These sterility effects has also been reported in cheetahs fed a feline diet of a soybean product, but reversed when the soybean product was removed from the diet. Saponin extracts from Quillaja saponaria (Francis et al., 2002), fenugreek (Trigonella foenum-graecum), soapbark tree (Quillaja saponaria) (Stadtlander et al., 2008), and Tribulus terrestris (Omitoyin et al., 2013), have also been reported to shifted the normal 50:50 male to female sex ratio of Nile tilapia larvae in favour of males with various degree of abnormalities in the gonad but with high sperm concentrations. Although these masculinization effects of saponin extracts have been explained by the fact that it able to elevate testosterone production (Ganzera et al., 2001), and increase sperm density (Adaikan et al., 2000; Gauthaman et al., 2002). However, the degenerative effect of PSM as demonstrated in this study is indicative of the fact that beyond an optimum level, testosterone production could be greatly decreased and sterility enhanced. This optimum point could be the focus of future research.

Bucholtz et al. (2008) had stated that gonadal development is a continuous process, but specific histological characteristics can be used to classify stages of gonadal development during the reproductive cycle. Omeje (2016) had also opined that $C$. papaya extract contain active ingredient that can caused pronounced hypertrophy, hyperplasia and gradual degeneration of the germ cells, sertoli cells and leydig cells, as well as germinal epithelium of both gonads. However, considering the fact that the PSM treatment was done in the fry stage of $O$. niloticus, the histological changes and degeneration observed in this study was less pronounced and severe that the studies of Ekanem and Okoronkwo (2003); Ekanem and Bassey (2003); Abbas and Abbas (2011) and Jegede and Fagbenro (2008). This is because the exposure periods in this study coincides with the period of gonadal differentiation which is estimated between $8-25$ days post hatching in tilapia (Nakamura and Takahashi, 1973). While the cited literatures were treated at post-juvenile stage after gonadal development has long taken place.

\section{REFERENCES}

Abbas, H.H. \& Abbas, W.T. 2011. Assessment study on the use of pawpaw; Carica papaya seeds to control Oreochromis niloticus breeding. Pak. J. Biol. Sci., 14: 1117-1123.

Abdelhak M.E., Madkour F.F., Ibrahim M.A., Sharaf M.S., Sharaf M.M. \& D.A, Mohammed. 2013. Effects of pawpaw, Carica papaya seeds meal on the productive performance and histological characters of gonads in Nile tilapia, Oreochromis niloticus. IJAR, 3 (12): 34-37.

Acharya, G., \& Mohanty, P. K. 2014. Comparative haematological and serum biochemical analysis of catfishes Clarias batrachus (Linnaeus, 1758) and Heteropneustes fossilis (Bloch, 1794) with respect to sex.

Adaikan, P. G., Gauthaman, K., Prasad, R. N., \& Ng, S. C. 2000. Proerectile pharmacological effects of Tribulus terrestris extract on the rabbit corpus cavernosum. Annals of the Academy of Medicine, Singapore, 29(1), 22-26

Ampofo-Yeboah A. 2013. Effect of Phytogenic Feed Additives on Gonadal Development in Mozambique Tilapia (Oreochromismossambicus). PhD Thesis, Stellenbosch University, South Africa.

Angeles I.P. \& Y-H Chien. 2015. Dietary effect of Quillaja saponaria and /or Yuccaschidigera extract on growth and survival of common carp Cyprinus carpio and theirantioxidant capacity and metabolic response upon low dissolved oxygen. 
The Israeli Journal of Aquaculture-Bamidgeh, IJA_64.2014.1165.

Ayotunde EO, Offem BO, Okey IB, Ikpi GU, Ochang SN, Agbam NE \& Omini DE. 2010. Toxicity of pawpaw ( Carica papaya ) seed powder to sharptooth catfish Clarias gariepinus fingerlings and effects on haematological parameters. International Journal of Fisheries and Aquaculture. 2(3): 71-78

Ayotunde, E.O. \& B.O. Ofem. 2008. Acute and chronic toxicity of pawpaw (Carica papaya) seed powder to adult Nile Tilapia (O. niloticus). Afr. J. Biotechnol. 7:2267 - 2274.

Babiak J, Babiak I, Nes SV, Harboe T, Haugen T \& Norberg B. 2012. Induced sex reversal using an aromatase inhibitor, Fadrozole, in Atlantic halibut ( Hippoglossus hippoglossus L .). Aquaculture. 324-325: 276-280.

Barros MM, Lim C, Klesius PH. 2002 Effect of iron supplementation to cotton seed meal diets on growth performance of channel catfish, Ictalurus punctatus. J Appl Aquac 10(65):86-92

Bucholtz, R.H.; Tomkiewicz, J. \& Dalskov, J. 2008. Manual to determine gonadal maturity of herring (Clupeaharengus L.). DTU Aqua-report 19708, Charlottenlund: National Institute of Aquatic Resources. pp. 45.

Campbell T.W. \& Murru F. 1990 An introduction to fish hematology. Compendium of Continuing Education in Veterinary Science, 12, 525-533.

Daneshvar E, Ardestani MY, Dorafshan S \& Martins ML. 2012. Hematological parameters of Iranian cichlid Iranocichla hormuzensis - Coad, 1982 (Perciformes) in Mehran river. Anais da Academia Brasileira de Ciencias. 84(4): 943-949.

Davis LK, Fox BK, Lim C, Lerner DT, Hirano T \& Grau EG. 2010. Effects of 11-ketotestosterone and fishmeal in the feed on growth of juvenile tilapia (Oreochromis mossambicus). Aquaculture. 305: 143-149.

De la Fuente J, Guillen I, Martinez R \& Estrada M. 1999. Growth regulation and enhancement in tilapia: basic research findings and their applications. Genetic Analysis: Biomolecular Engineering. 15: $85-90$.

De Pedro N, Guijarro Al, López-Patiño MA, MartínezÁlvarez R \& Delgado MJ. 2005. Daily and seasonal variations in haematological and blood biochemical parameters in the tench, Tinca tinca Linnaeus, 1758. Aquaculture Research. 36(12): 1185-1196.

Drabkin D.R. 1945 Crystallographic and optical properties of human hemoglobin: a proposal for the standardization of hemoglobin. American Journal of the Medical Sciences 209, 268-270.

Ekanem, S.B. \& Bassey, P.O. 2003. Effect of pawpaw seed (Carica papaya) as antifertility agent in female
Nile tilapia (Oreochromis niloticus). J. Aquac. Trop., 18 (2): 181-188.

Ekanem, S.B. \& T.E. Okoronkwo. 2003. Pawpaw seed as a fertility control agent on male Nile tilapia. NAGA. World Fish Centre Q., 26:8 - 10.

EI - Sayed, A.F.M. 2006. Tilapia culture. CAB International, Walling Ford, UK, Pp. 304.

El-Naga E.H.A. Khalid M, Moselhy EL \& Hamed M.A. 2005. Toxicity of cadmium and copper and their effects on some biochemical parameters of marine fish Mugil seheli Egypt Journal of Aquactic Research. 31: 60-71.

FAO. 2002. Fish Stat. Plus - Universal Software for fishery statistical time series.

Francis G., Levavi-Sivan B., Avitan A. \& K. Becker. 2002. Effects of long term feeding Quillaja saponins on sex ratio, muscle and serum cholesterol and LH levels in Nile tilapia (Oreochromis niloticus L). Comp. Biochem. Phys. C, 133: 593-603.

Francis G., Makkar H.P.S. \& K. Becker, 2001. Effects of Quillaja saponins on growth, metabolism, egg production, and muscle cholesterol in individually reared Nile tilapia (Oreochromis niloticus). Comp. Biochem. Phys. C, 129:105-114.

Francis G., Makkar H.P.S. \& K. Becker. 2005. Quillaja saponins - a natural growth promoter for fish. Anim. Feed Sci. Tech., 121: 147-157.

Ganzera M., Bedir E. \& I.A. Khan. 2001. Determination of steroidal saponins in Tribulus terrestris by reversed-phase high-performance liquid chromatography and evaporative light scattering detection. J. Pharm. Sci.,90: 1752-1758.

Gauthaman K., Adaikan P.G. \& R.N.V Prasad. 2002. Aphrodisiac properties of Tribulus terrestris extract Protodioscin) in normal and castrated rats. Life Sciences, 71: 1385-1396.

Jegede T, 2010. Control of reproduction in Oreochromis niloticus (Linnaeus 1758) using Hibiscus rosasinensis (Linn.) leaf meal as reproduction inhibitor. J. Agr. Sci., 2: 149- 154.

Jegede T. 2011. Effects of Aloe vera (Liliaceae) on the gonad development in Nile tilapia (Oreochromis niloticus) (Linnaeus 1758). In: Fitzsimmons, K., \& Liping, $L$ (eds), Proceedings of the 9th International symposiums on tilapia aquaculture, 222-227 pp. Aquafish CRSP, Shanghai, China.

Jegede, T. \& O. Fagbenro. 2008. Histology of gonads in Oreochromis niloticus (Trewaves) fed pawpaw (Carica papaya) seed meal diets. Proceedings of the 8th International Symposium on Tilapia in Aquaculture, October 12 - 14, 2008 Cairo, Egypt, pp: $1135-1141$.

Karimi S, Kochinian P \& Salati AP. 2013. The effect of sexuality on some haematological parameters of the yellowfin seabream, Acanthopagrus latus 
in Persian Gulf. Iranian Journal of Veterinary Research. 14(1): 65-68.

Kavitha C, Ramesh M, Kumaran SS \& Lakshmi A. 2012. Toxicity of Moringa oleifera seed extract on some hematological and biochemical profiles in a freshwater fish, Cyprinus carpio. Experimental and Toxicologic Pathology. 64(7-8): 681-687.

Klinger, R.C, Blazer, V.S., Echevarria, C. 1996. Effects of dietary lipid on the haematology of channel catfish, Ictalurus punctatus. Aquaculture 147:225-233.

Kobayashi, H.C. Wang \& K.W. Pauper. 2008. Phenolic content and antioxidant capacity of pawpaw fruit (Asimina triloba L.) at different ripening stages. Hortscience, 43:268 - 270.

Luna, L. G. 1992. Histopathologic methods and color atlas of special stains and tissue artifacts. Amer Histolabs Pub Dept.

Meyer, D.E. 2002. Technology for successful smallscale tilapia culture (CRSP Research Report 02179). CRSP (Aquaculture collaborative research support program. [Abstract from original paper published in D. Meyer (Ed). Tilapia sessions, 22-24 August 2001, p. 97-106.

Nakamura, M. \& H. Takahashi, 1973. Gonadal sex differentiation in Tilapia mossambica with special regard to the time of estrogen treatment effective in inducing feminization of genetic fishes. Bull. Fac. Fish., Hokkaido Univ., 24: 113.

Olufeagba S.O. \& Okomoda V. T. 2015. Preliminary report on the use of Androgen for the production of All-male Oreochromis niloticus. International Journal of Aquaculture. Volume 5 (9) Pp 1-3.

Omeje. 2016: Effect of Pawpaw (Carica papaya) seed meal on the reproductive, endocrine and immune system of Mozambique tilapia (Oreochromis mossambicus). Ph.D Dissertation, Faculty of Agrisciences, Stellenbosch University, South Africa. 159pp.

Omitoyin B.O., Ajani E.K. \& H.O. Sadiq. 2013. Preliminary investigation of Tribulus terrestri (Linn, 1753) extracts as natural sex reversal agent in Oreochromis niloticus (Linn. 1758) larvae. Int. J. Aquacult., 3:133-137.

Ozovehe B.N. 2012. Growth Performance, Haematological Indices and Some Biochemical Enzymes of Juveniles Clarias gariepinus (Burchell 1822) Fed Varying Levels of Moringa oleifera Leaf Meal Diet. Journal of Aquaculture Research \& Development. 04(02): 2-7.

Pandian, T.J. \& K. Varadaraj. 2005. Development of monosex female Oreochromis mossambicus broodstock by integrating gynogenetic technique with endocrine sex reversal J. Exp. 200L, 255:88 $-96$.
Rapatsa M.M. \& Moyo N.A. 2013. Haematological, histological and growth characteristics of Oreochromis mossambicus exposed to effective microorganisms in organically manured aquadams. Asian Journal of Animal and Veterinary Advances. 8(7): 852-862.

Santos AA, Egami MI, Ranzani-paiva MJT \& Juliano Y. 2009. Hematological parameters and phagocytic activity in fat snook ( Centropomus parallelus ): Seasonal variation, sex and gonadal maturation. Aquaculture. 296: 359-366.

Shah S.L., \& Altindag A. 2004. Haematological parameters of tench (Tinca tinca L.) after acute and chronic exposure to lethal and sublethal mercury treatments. Bull. Environ. Contam. Toxicol. 73: $911-918$

Solomon S.G. \& Okomoda V.T. 2012: Effects of photoperiod on the haematological parameters ofClarias gariepinus fingerlings reared in water recirculatory system. Journal of Stress Physiology and Biochemistry, ISSN 1997-0838. Vol. (8) Pp. 247-253.

Stadtlander, T., Levavi-Sivan, B., Dweik, H., Qutob, M., Abu-Lafi, S., Kerem, Z., ... \& Becker, K. 2008. Treatment with saponins from Trigonella foenumgraecum and Quillaja saponaria influences sex ratio in Nile tilapia, Oreochromis niloticus L., larvae. Saponin fractions from fenugreek (Trigonella foenum-graecum L.) as dietary supplements for Nile tilapia (Oreochromis niloticus L.) and common carp (Cyprinus carpio L.), 13.

Toguyeni A, Fauconneau B, Fostier A, Abucay J, Mair G \& Baroiller JF. 2002. Influence of sexual phenotype and genotype, and sex ratio on growth performances in tilapia, Oreochromis niloticus. Aquaculture. 207: 249-261.

Udoh, P. \& A. Kekinde. 1999. Studies on antifertility effect of pawpaw seeds (Carica papaya) on the gonads of male albino rats. Phytother res. 13:226 $-228$.

Vázquez RG \& Guerrero GA. 2007. Characterization of blood cells and hematological parameters in Cichlasoma dimerus (Teleostei, Perciformes). Tissue and Cell. 39(3): 151-160.

Wagner E.J., Jensen T., Arndt R., Routedge M.D., Brddwisch Q. 1997. Effects of rearing density upon cut throat trout haematology, hatchery performance, fin erosion and general health and condition. The Prog. Fish-Cult. 59 : 173-187.

Submetido: Janeiro/2017 Revisado: Março/2017 Aceito: Outubro/2017 